\title{
USING AUTODESK INVENTOR SOFTWARE FOR MODELLING WORK PROCESSES OF SINGLE-BUCKET LOADERS
}

\author{
Yefymenko O., Hrichchina A., KhNAHU
}

\begin{abstract}
The scientific problem is to evaluate the results of using Autodesk Inventor software for modelling work processes specific to single-bucket loaders. The basis for this scientific research is the fundamental knowledge that allows using the ideas concerned with virtual models and the possibility of their further application. The goal of the study is to analyse work processes of loaders using computer modelling facilities. Methodology. Research methodology includes the methods of finite elements, the use of software tools for the application of computer programs for modelling the loader dynamics and conducting experiments using a personal computer. Results. The results of the research are the graphical and mathematical dependences of the values which have been estimated experimentally. Originality. The present paper allowed carrying out the research of the single-bucket loaders' dynamics in the following aspects: moving across an obstacle, running over an insurmountable obstacle, a sharp brake of the loader. Practical value. The method of using the Autodesk Inventor software for modelling the dynamics of the loader has been developed. The basic kinematic parameters and the support reactions for a wheel moving across obstacles have been determined for various designs of single-bucket loaders.
\end{abstract}

Key words: modelling, work process, virtual laboratory, Inventor.

\section{Introduction}

The topicality of the present paper results from the growing application of loaders both in the construction of roads and during their usage. The basis for this scientific research is the fundamental knowledge that allows using the topic of virtual models and the possibility of their further application.

Research methodology includes the methods of finite elements, the use of software tools for the application of computer programs for modelling the loader dynamics and conducting experiments using a personal computer.

The introduction of a new technique for analyzing the dynamics of loaders' working and transport modes takes the process of solving dynamic analysis tasks to a new level. In the field of product performance dynamic analysis, this is similar to the transition of design departments from the production of paper drawings to the use of automated design systems. The technology of automated dynamic analysis allows us to simplify and accelerate the solution of mathematical modelling tasks and thus to significantly improve the efficiency of the development of new engineering products.

\section{Recent Papers Review}

At present, modern methods of designing and analyzing earth-moving machines using the Autodesk Inventor software are widely used.
Major benefits of automated dynamic analysis are:

- automatic construction of a mathematical model of the mechanical system dynamics according to its engineering description;

- visualization of the mechanical system work process and the values of its properties [1,2];

- wide possibilities for controlling the movement of the mechanical system [3].

The use of automated dynamic analysis allows to obtain reliable information about the dynamic behaviour of the products at the early stages of their design and the power loads that arise, as well as to quickly and effectively deal with abnormal situations which can emerge during the operation of existing products [4-6].

\section{Purpose and Tasks}

The purpose of the paper is to analyse work processes of loaders using computer modelling facilities.

\section{Modeling Work Processes of Loaders}

The initial step is to build the most detailed 3D model of the loader using the Autodesk Inventor software.

The stage of exporting a ready threedimensional model into the Autodesk Inventor program is very important. It is critical to preserve the mass-inertial characteristics of assembly units of the three-dimensional model after 
export. The next step is to break up all the assembly units obtained into movable and immovable objects. For example, a wheel is movable (rotational motion) relative to the axis on which it is fixed. Once all movable parts have been determined, it is necessary to conduct a complete kinematic analysis of the model. After receiving these data, it is necessary to make kinematic pairs of all the parts using hinges. For example, the process of connecting the parts of a HITACHI loader weighing 25 tons and ensuring rotation of the driving wheels, as well as simulating the loader movement in a specific direction is shown in Figures 1 and 2.

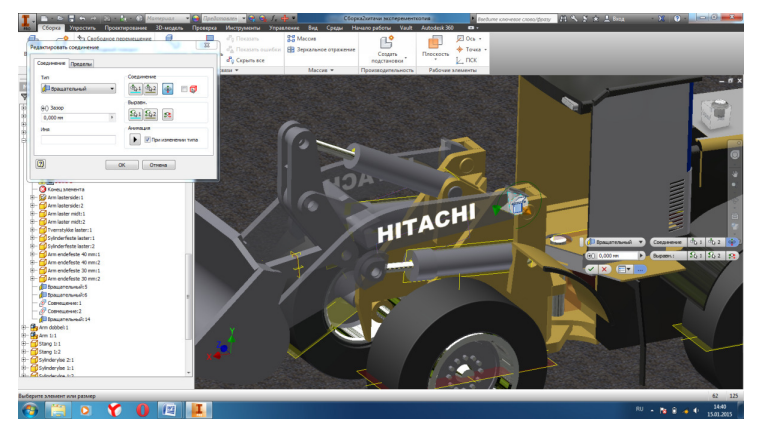

Fig. 1. Connecting the arm and the frame of a loader into a kinematic pair

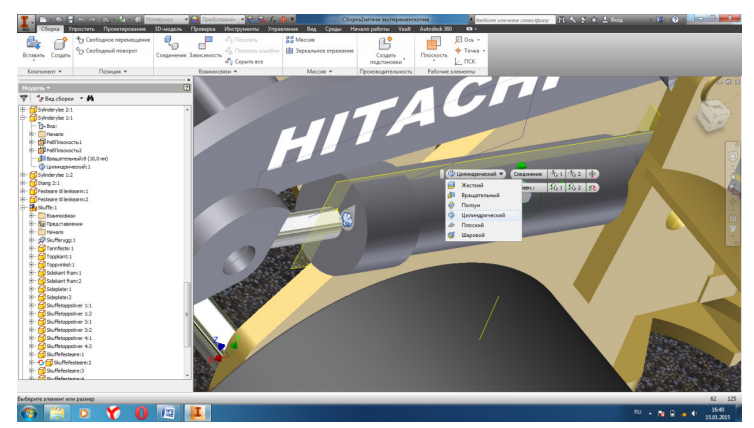

Fig. 2. Connecting the hudraulic cylinder rod

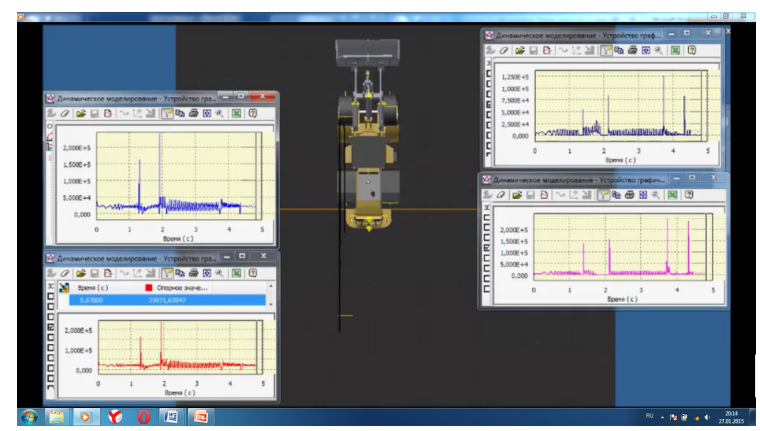

Fig. 3. Waveforms for support reactions on drive wheels of a Hitachi loader

The model given above enables us to conduct a preliminary analysis of the structure.
Figure 3 shows the forces that arise in the wheels of a HITACHI loader weighing 25 tonnes when it moves across an obstacle of a length of $70 \mathrm{~mm}$ and a width of $30 \mathrm{~mm}$, at a speed of $5 \mathrm{~km} / \mathrm{h}$. After the computer experiment was finished, waveforms of support reactions were built and then convrted into MSEXCEL with the preliminary analysis (Figure 4).

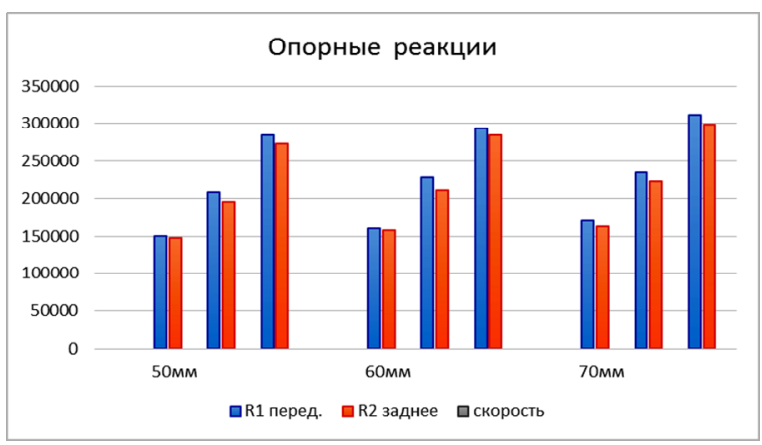

Fig. 4. Waveforms for support reactions

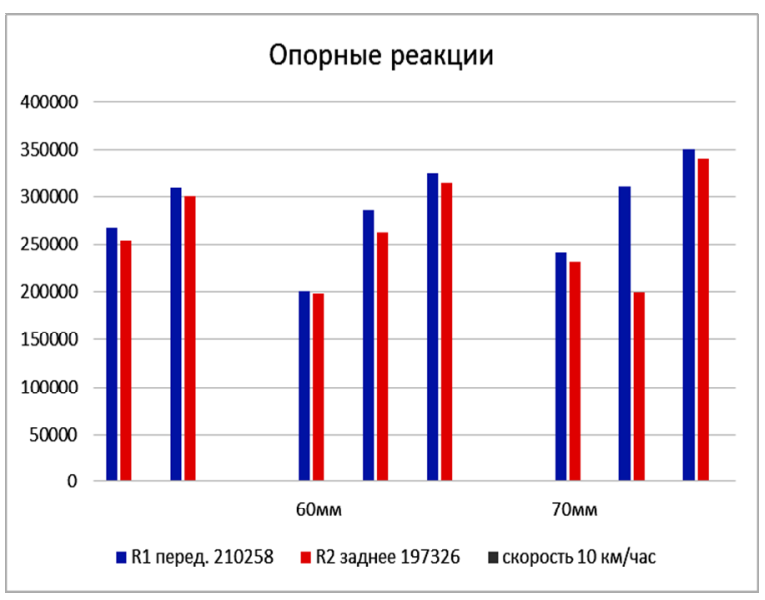

Fig. 5. Waveforms for support reactions

Similarly, experiments with other loaders such as Sankar Ram and Cat (compact) were conducted. Data were obtained, converted into MSEXEL and then analyzed, which allowed us to construct graphs for the redistribution of support reactions along two axes (Figure 5).

The models of dynamic processes which arise when vehicles move across a single obstacle showed us a number of results that cannot be measured directly in a real experiment, in particular, it is impossible to determine how support reactions on each of the wheels change over time. The virtual experiment has shown that when a loader moves across a single obstacle in a transport mode, the support reactions change over time in accordance with the laws which are similar to oscillating processes. 


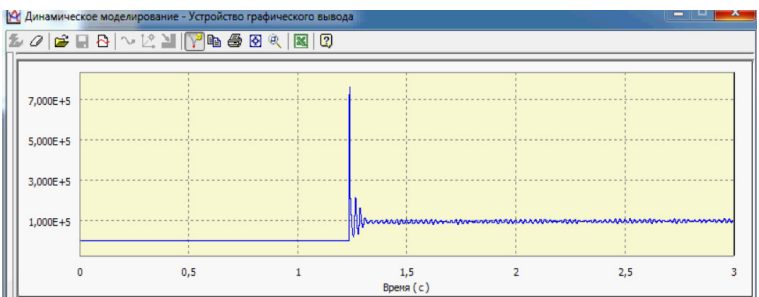

Fig. 6. Tractive effort of a Sankar Ram loader

Figure 6 shows the tractive effort that arises in the metalwork of a loader weighing $15 \mathrm{t}$ in the event of a collision of the working equipment with an impassable obstacle. The speed remains unchanged, it is $5 \mathrm{~km} / \mathrm{h}$. The vehicle continues its movement, and in the interval between the 1st and 2nd seconds there occurs a collision of the bucket with an obstacle. During this time, the maximum effort is registered which equals $7 \times 10^{5} \mathrm{H}$.

The waveforms of all vehicles and their results were analyzed in the paper. Loaders' axle tractive efforts arising at the collision with an impassable obstacle are shown in Figure 7.

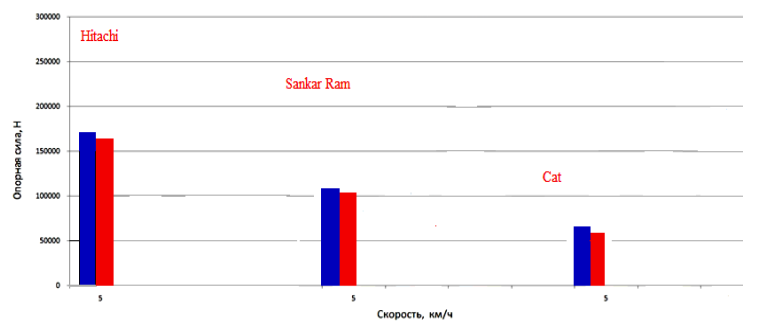

Fig. 7. Loaders' axle tractive effort values

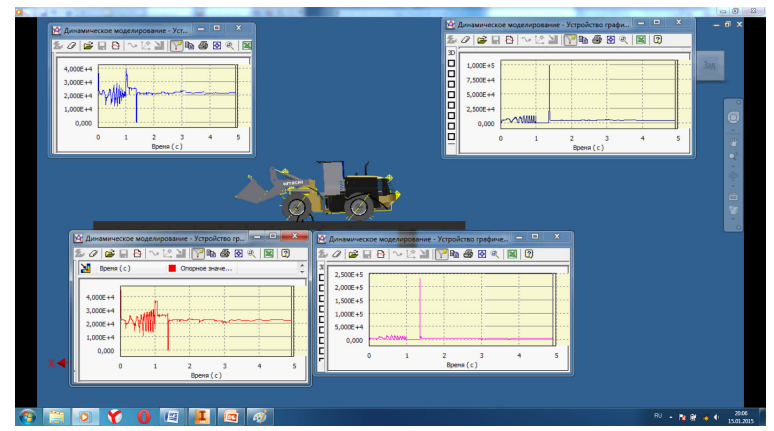

Fig. 8. Determination of hard brake support reactions (Hitachi loader)

When determining the support reactions for a sharp deceleration of a Hitachi loader, an emergency braking of the vehicle was considered and the required reactions on the axles were obtained (Figure 8).

Similarly, the support reactions for other loaders have been determined. The support reac- tions for Sankar Ram and Cat (compact) loaders are shown in Figures 9 and 10.

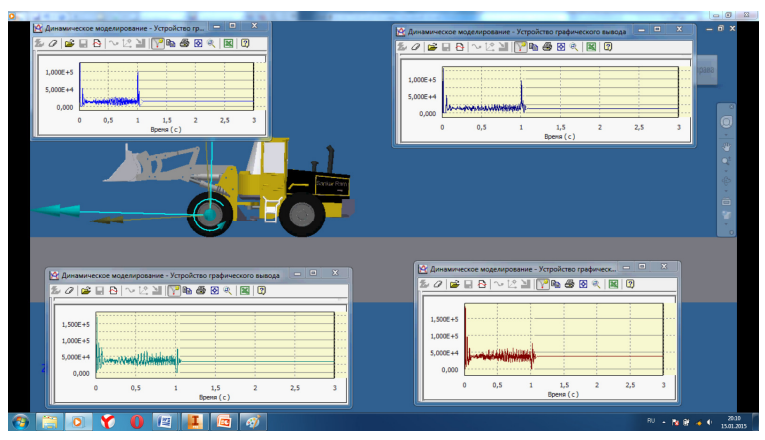

Fig. 9. Determination of hard brake support reactions for a Sankar Ram loader

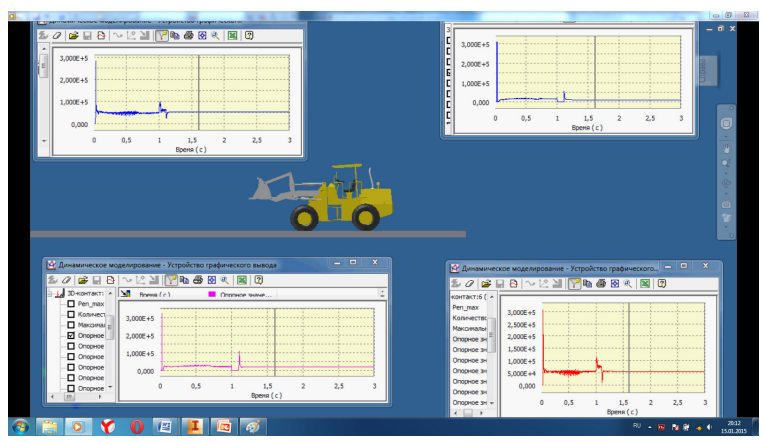

Fig. 10. Determination of hard brake support reactions for a Cat loader (compact)

During the experiment it was found that a vehicle with a higher coefficient of friction and a higher weight has the highest rates. Thus, for a Hitachi loader R1 $=132000 \mathrm{~N}, \mathrm{R} 2=128258 \mathrm{~N}$, then comes Sankar Ram loader R1 $=68258 \mathrm{~N}$, $\mathrm{R} 2=69585 \mathrm{~N}$ and Cat $\mathrm{R} 1=35689 \mathrm{~N}$, $\mathrm{R} 2=37589 \mathrm{~N}$.

Successful experience in the development of theoretical foundations and the practical implementation of complex system models suggests their huge potential in the field of mechanical engineering and road building. The development of simulation models of such systems is iterative and is based on the design of individual modules and subsystems and their integration into a single entity on the basis of dynamic analysis and the use of modern tools for the creation of intelligent applications.

This will simplify and accelerate the solution of the mathematical modelling tasks, improve the efficiency of complex machinery design processes as well as enable the implementation of simulation experiments.

The advantages of using automated dynamic analysis for the formation of a mathematical model of mechanical system dynamics; visuali- 
zation of the work process; control of the mechanical system movement have been explained.

The reliable information about dynamic behaviour of created objects and the power load that arise can be obtained in the early stages of their design. Besides, it is possible to conduct real-time research of abnormal situations that arise during the operation.

The purpose of this paper was to to analyse work processes of loaders using computer modelling facilities. The Autodesk Inventor software package allowed to conduct an experiment on the wheel movement on the supporting surface with an obstacle with the same mass characteristics, material and height and shape of the obstacle. For the experiment, a treaded tire and a slick tire were taken. Main characteristics for modelling were: the height and width of the obstacle equaled $100 \mathrm{~mm}$, wheel speed equaled $5 \mathrm{~km} / \mathrm{h}$.

For the process of dynamic modelling in $\mathrm{Au}-$ todesk Inventor the following parameters were set: 3D contact between the wheel and the supporting surface, the connection of the wheel with the supporting surface taking into account all degrees of freedom.

Dynamic modelling characteristics of various types of wheels moving across a single obstacle were defined.

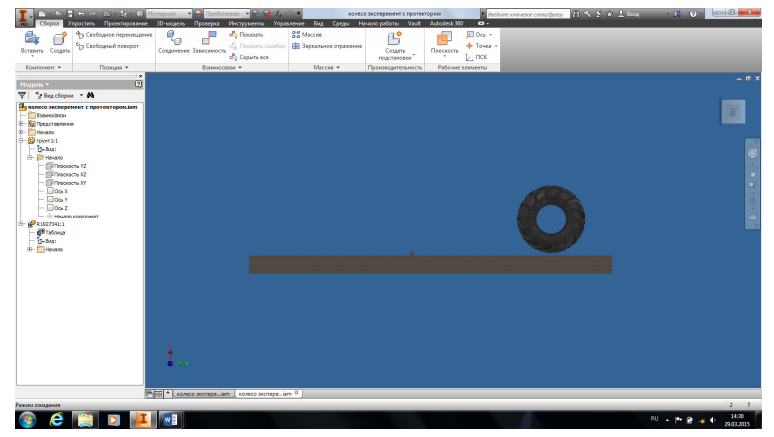

Fig. 11. Movement of a wheel on the supporting surface with an obstacle

In order to determine the reactions in the supports, it is necessary to simulate the movement of the wheel across an obstacle using the menu of dynamic simulation and introducing a 3D contact between the wheel and the surface and the necessary rigidity and friction parameters.

In the simulation, a browser tree was used to determine the kinematic pair responsible for wheel rotation, graphs of gradual speed-up of the wheel over a period of time were constructed, the type of soil as a basic element was identified, materials and mass characteristics of the parts were determined. The analysis of the model is shown in the Figure 12.

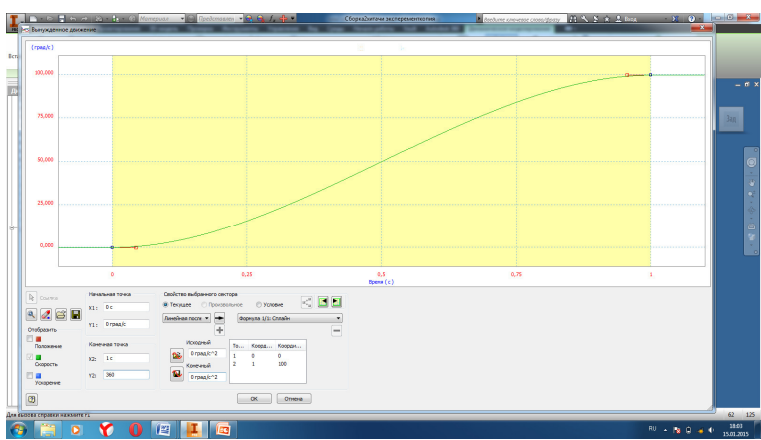

Fig. 12. Movement chart for a wheel following the trajectory

Thus, a virtual experiment and a simulation have been conducted using the AutoDesk Inventor software. The basic kinematic parameters and the support reactions for a wheel moving across obstacles have been determined for various designs of single-bucket loaders.

\section{Conclusion}

The method of using the Autodesk Inventor software for modelling the dynamics of the loader has been developed, which allowed carrying out the following parts of the research: moving across an obstacle, running over an insurmountable obstacle, a sharp brake of the loader. The results of the research are the graphical and mathematical dependences of the values.

During the tests, the advantages of computer modelling of construction machinery work processes have been confirmed.

The tests also revealed the influence of the machine mass and the type of tires on the kinematic parameters of its motion.

The next step of the present research should be validation of a model for adequacy to real machines and a more thorough study of the influence of various factors on the results of computer experiments.

\section{References}

1. Waguespack, C., Jahraus, L. Mastering Autodesk Inventor 2010. Wiley Publishing, Inc., Indianapolis, Indiana, 2009.

2. Бондаков Б.Ф. Справочник конструктора дорожных машин: справочник / Б.Ф. Бондаков, С.А. Варганов. - М.: Машиностроение, 1973. - 158 с.

3. Гоберман Л.А. Теория, конструкция и расчет строительных и дорожных машин: учебник для техникумов / Л.А. Гоберман. - М.: Машиностроение, 1979. - 232 с.

4. Каширин А. Ю. Приемы проектирования деталей AUTODESK INVENTOR / А. Ю. Каширин. - М.: Самиздат, 2006. $202 \mathrm{c}$. 
5. Палеев В. А. Строительные и дорожные машины / В. А. Палеев, С. Ю. Тимаков // Вестник СибАДИ. - 2009. - №5. - С. 4752.

6. Раннев А. В. Строительные машины. Справочник / А. В. Раннев. - М.: Машиностроение, 1991. - $177 \mathrm{c}$.

7. Тремблей T. Autodesk Inventor 2013 и Inventor LT ${ }^{\mathrm{TM}}$ 2013. Основы. Официальный учебный курс / Т. Тремблей. - М.: ДМК Пресс, 2013. - 244 с.

\section{References}

1. Waguespack, C., Jahraus, L. (2009). Mastering Autodesk Inventor 2010. Indianapolis: Wiley Publishing, Inc.

2. Bondakov, B. F. (1973). Spravochnik konstruktora dorozhnyh mashin [Roadbuilding machinery design guide]. Moscow: Mashinostroenie [in Russian].

3. Goberman, L. A. (1979). Teorija, konstrukcija $i$ raschet stroitelnyh $i$ dorozhnyh mashin [Theory, design and calculation of roadbuilding and construction machinery: Textbook for technical schools]. Moscow: Mashinostroenie [in Russian].

4. Kashirin, A. Ju. (2006). Priemy proektirovanija detalej AUTODESK INVENTOR [Techniques for designing components in AUTODESK INVENTOR]. Moscow: Samizdat [in Russian].

5. Paleev, V. A., Timakov, S. Ju. (2009). Stroitelnye i dorozhnye mashiny [Construction and Road-Building Machines]. Vestnik SibADI - Bulletin SibADI, 5, 47-52 [in Russian].

6. Rannev, A. V. (1991). Stroitelnye mashiny [Construction machines]. Moscow: Mashinostroenie [in Russian].

7. Tremblay, T. (2013). Autodesk Inventor $2013 i$ Inventor LTTM 2013. Osnovy. Oficialnyj uchebnyj kurs [Autodesk Inventor 2013 and Inventor LT ${ }^{\mathrm{TM}}$ 2013. Basics. Formal Textbook]. Moscow: DMK Press [in Russian].

Yefymenko O., Associate Professor, Cand. Sc. (Eng.), 0950124262, alef@gmail.com

Department of Construction and Earthmoving

Hrichchina A., Senior Lecturer, +380577073721, grichchina@ukr.net

Foreign Languages Department

Kharkiv National Automobile and Highway University,

Yaroslava Mudroho Str., 25 Kharkiv 61002,

\section{МОДЕЛЮВАННЯ РОБОЧИХ ПРОЦЕСІВ ОДНОКІВШЕВИХ НАВАНТАЖУВАЧІВ ЗА ДОПОМОГОЮ «АUTODЕSK INVENTOR»}

\author{
Єфименко О.В., Гріччіна А.В., ХНАДУ
}

Анотація. Наукова проблема полягає в оиіниі результатів використання програмного забезпечення Autodesk Inventor для моделювання робочих процесів, характерних для одноківшевих навантажувачів. Базовою основою для иього наукового дослідження є фундаментальні знання, які дозволяють використовувати ідеї та досвід, що стосуються віртуальних моделей, $і$ можливість їх подальшого застосування. Метою дослідження $\epsilon$ аналіз робочих прочесів навантажувачів з використанням засобів комп'ютерного моделювання. Методика дослідження включає в себе методи кінцевих елементів, використання програмних засобів для застосування комп'ютерних програм для моделювання динаміки одноківщевого навантажувача та проведення експериментів з використанням персонального комп'ютера. Технологія автоматизованого динамічного аналізу дозволяє спростити і прискорити вирішення завдань математичного моделювання $i$, зрештою, істотно підвищити ефективність розробки нової науково-технічної продукиї. Результатами иього дослідження стали графічні та математичні залежності значень, які були отримані експериментально. В ході усіх випробувань було виявлено також вплив маси матини і типу шин на кінематичні параметри руху. Вказаний підхід дозволив провести дослідження динаміки одноківшевих навантажувачів у наступних аспектах: переїзд через перешкоду, наїзд на неприступну перешкоду, різке гальмування навантажувача. Практичне значення дослідження полягає в тому, що було розроблено метод використання програмного забезпечення Autodesk Inventor для моделювання динаміки навантажувача. Основні кінематичні параметри та реакиї підтримки для коліс, щзо рухаються через перешкоди, були визначені для різних конструкцій одноківшевих навантажувачів.

Ключові слова: моделювання, робочий прочес, віртуальна лабораторія, Inventor.

\section{МОДЕЛИРОВАНИЕ РАБОЧИХ ПРОЦЕССОВ ОДНОКОВШОВЫХ ПОГРУЗЧИКОВ С ПОМОЩЬЮ «АUTODESK INVENTOR»}

\section{Єфименко О.В., Гріччіна А. В., ХНАДУ}

Аннотация. Приведень результать моделирования рабочих процессов одноковшовых погрузчиков с помощью программного комплекса Autodesk Inventor. Определень основнье кинематические параметры и опорные реакции при переезде колеса через препятствия при использовании различных конструкиий одноковшовых погрузчиков.

Ключевые слова: моделирование, рабочий прочесс, виртуальная лаборатория, Inventor. 